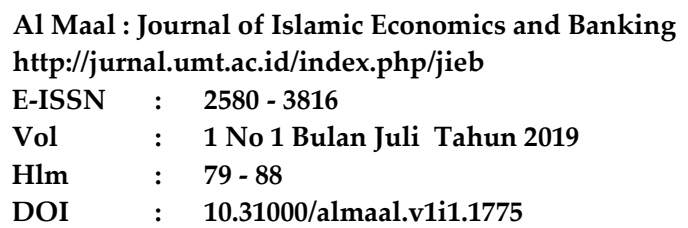

\title{
Telaah Kritis Akad Musyarakah Mutanaqisah
}

\author{
Muh Turizal Husein ${ }^{1, *}$ \\ ${ }^{1}$ Universitas Muhammadiyah Tangerang, Indonesia \\ *Email : abiturizal68@gmail.com,
}

\begin{abstract}
Since the opening of the MEA door in 2015 to 2020, it will be colored by a strategy competition and a tighter level of financial services business competition. Sharia Banking products based on partnerships with "profit-loss sharing" such as Musyarakah currently have not shown significant growth like other products. One of the musyarakah derivative contracts that has the potential to be practiced as an innovation product in Islamic banking is the musyarakah mutanaqisa contract. This study examines the need for living space for customers by using musyarakah mutanaqisa agreement and musyarakah mutanaqisa practice in Indonesia. This study uses a qualitative approach with descriptive analysis design. In Indonesia, only a few Sharia Banks have offered financing products with mutanaqisa musyarakah contracts, namely Sharia Maybank, Panin Sharia Bank, Mega Syariah Bank and Bank Muamalat. Of the four BUSs, the products they offer have ownership of assets namely home ownership and vehicles. But in their practice they still give customers the choice in choosing, which contract they will use. such as murabahah contracts in home ownership products and vehicles.
\end{abstract}

Keywords: Musyarakah; Mutanaqisa; Profit; Banks

\section{ABSTRAK}

Sejak dibukanya pintu MEA pada 2015 sampai 2020 nanti, akan diwarnai oleh adu strategi dan tingkat kompetisi bisnis jasa keuangan yang semakin ketat. Produk perbankan Syariah berbasis kemitraan dengan "profit-loss sharing" seperti Musyarakah saat ini belum menunjukkan pertumbuhan yang signifikan seperti produk lain. Salah satu kontrak derivatif musyarakah yang berpotensi dipraktekkan sebagai produk inovasi dalam perbankan Islam adalah kontrak musyarakah mutanaqisa. Studi ini meneliti tentang kebutuhan tempat tingal bagi nasabah dengan menggunakan akad musyarakah mutanaqisa dan praktek musyarakah mutanaqisa di Indonesia. Penelitian ini menggunakan pendekatan kualitatif dengan desain analisis deskriptif. Di Indonesia baru sedikit Bank Syariah yang menawarkan produk pembiayaan dengan akad musyarakah mutanaqisa, yaitu Maybank Syariah, Panin Bank Syariah, Bank Mega Syariah dan Bank Muamalat. Dari Keempat BUS tersebut produk yang mereka tawarkan kepemilikan aset yakni kepemilikan rumah dan kendaraan. Namun dalam perakteknya mereka masih memberi pilihan kepada nasabah dalam menenukan pilihan, akad mana yang akan mereka gunakan. seperti akad murabahah dalam produk kepemilikan rumah dan kendaraan.

Kata kunci: Musyarakah; Mutanaqisa; Profit; Bank 


\section{Pendahuluan}

Daya tarik masyarakat dewasa ini terhadap perbankan syariah mengalami peningkatan, hal ini tampak dari bertambahnya segmen dan jumlah nasabah. Seiring meningkatnya animo masyarakat akan perbankan syariah, maka hal ini mendorong lembaga syariah ini untuk terus melakukan pengembangan dan inovasi produk yang ditawarkan agar mampu semakin menarik minat masyarakat, serta mampu menjawab kebutuhan masyarakat saat ini. Disamping itu, perbankan syariah harus memastikan bahwa produk yang ditawarkan telah sesuai dengan prinsip syariah, karena inilah hal pokok yang membedakan bank syariah dan bank konvensional.

Produk berbasis kemitraan dengan bagi hasil seperti musyarakah sebagai produk unggulan kompetitif perbankan syariah belum mengalami pertumbuhan sebagaimana produk lainnya. Kurangnya pengembangan produk berbasis kemitraan diperbankan syariah yang lebih fleksibel jangka waktunya, terutama pembiayaan jangka panjang menyebabkan perbankan syariah lebih banyak produknya didasari oleh pembiayaan dengan pendapatan tetap yang memiliki kemiripan dengan pola konvensional yang menggunakan struktur pendapatan yang tetap (fixed income) dan cenderung berjangka waktu pendek dan menengah. Bank-bank syariah harus memiliki standar produk yang memadai untuk menjamin kepastian ketentuan operasional yang prudent dan perlindungan konsumen serta platform bagi pengembangan dan inovasi produk yang semakin beragam agar bisa berkembang dengan baik. Upaya ini mutlak dilakukan karena bank syariah akhir-akhir ini cenderung mengalami pelambatan pertumbuhan bahkan penurunan market share secara dinamis dibanding konvensional. Standarisasi dan inovasi produk perbankan syariah adalah sebuah keniscayaan, agar perbankan syariah bertumbuh secara wajar, seimbang dan berkelanjutan serta mampu bersaing dengan perbankan lain.

Produk berbasis kemitraan dengan bagi hasil seperti musyarakah sebagai produk unggulan kompetitif perbankan syariah belum mengalami pertumbuhan sebagaimana produk lainnya. Kurangnya pengembangan produk berbasis kemitraan diperbankan syariah yang lebih fleksibel jangka waktunya, terutama pembiayaan jangka panjang menyebabkan perbankan syariah lebih banyak produknya didasari oleh pembiayaan dengan pendapatan tetap yang memiliki kemiripan dengan pola konvensional yang menggunakan struktur pendapatan yang tetap (fixed income) dan cenderung berjangka waktu pendek dan menengah. Bank-bank syariah harus memiliki standar produk yang memadai untuk menjamin kepastian ketentuan operasional yang prudent dan perlindungan konsumen serta platform bagi pengembangan dan inovasi produk yang semakin beragam agar bisa berkembang dengan baik. Upaya ini mutlak dilakukan karena bank syariah akhir-akhir ini cenderung mengalami pelambatan pertumbuhan bahkan penurunan market share secara dinamis dibanding konvensional. Standarisasi dan inovasi produk perbankan syariah adalah sebuah keniscayaan, agar perbankan syariah bertumbuh secara wajar, seimbang dan berkelanjutan serta mampu bersaing dengan perbankan lain.

Diantara Produk berbasis kemitraan dengan bagi hasil seperti musyarakah sebagai produk unggulan kompetitif perbankan syariah adalah Produk Kredit Pemilikan Rumah yang nantinya akan di sebut (KPR). Produk ini bisa menjadi sebuah solusi untuk masyarakat yang ingin memiliki rumah namun tidak memiliki banyak dan untuk membelinya secara tunai. Umumnya perbankan konvensional dalam memberikan fasilitas KPRnya mengunakan sistem bunga yang identik dengan riba yang sudah jelasjelas keharamannya dalam hukum Islam. Di sisi yang lain kebutuhan masyarakat untuk 
memiliki sebuah rumah semakin meningkat tiap tahunya, menurut data yang dikeluarkan oleh Badan Pusat Statistik (BPS) pada tahun 2015, diperkirakan jumlah supply pembangunan rumah pertahun hanya sekitar 400 sampai 500 ribu unit rumah. Padahal kebutuhan rumah bagi masyarakat per tahun sekitar 800 ribu unit rumah dan kekurangan kebutuhan (backlog) perumahan saat ini sudah mengalami penurunan dari 13,5 juta unit menjadi sekitar 11,4 juta unit rumah (www.bps.go.idg 2015). Dari data di atas menunjukan bahwa minat masyarakat akan kepemilikan rumah semakin meningkat tiap tahunya, bahkan pembangunan yang dilakukan saat ini masih belum bisa memenuhi permintaan dari masyarakat yang tiap tahunya mengalami peningkatan terlebih lagi menjadi perhatian khusus yaitu ketika seseorang yang ingin memiliki sebuah rumah tidak mampu untuk membelinya secara kontan karena keterbatasan dana yang tidak di miliki.

\section{KAJIAN LITERATUR}

Musyarakah Mutanaqisah berasal dari dua kata Musyarakah dan Mutanaqisah. Musyarakah (syaraka-yusriku-syarkan-syarikan-syirkatan-syirkah), yang berarti bekerja sama, berkongsi, berserikat, atau bermitra (cooperation, partnership) dan Mutanaqisah (yatanaqishu-tanaqishan-mutanaqishun) berarti mengurangi secara bertahap (to diminish). Musyarakah mutanaqisah adalah musyarakah atau syirkah yang kepemilikan asset (barang) atau modal salah satu pihak (syarik) berkurang disebabkan pembelian secara bertahap oleh pihak lainnya.

Produk berbasis kemitraan dengan bagi hasil seperti musyarakah sebagai produk unggulan kompetitif perbankan syariah belum mengalami pertumbuhan sebagaimana produk lainnya. Diantara Produk berbasis kemitraan dengan bagi hasil seperti musyarakah sebagai produk unggulan kompetitif perbankan syariah adalah Produk Kredit Pemilikan Rumah yang nantinya akan di sebut (KPR). Produk ini bisa menjadi sebuah solusi untuk masyarakat yang ingin memiliki rumah namun tidak memiliki banyak dan untuk membelinya secara tunai. Umumnya perbankan konvensional dalam memberikan fasilitas KPRnya mengunakan sistem bunga yang identik dengan riba yang sudah jelasjelas keharamannya dalam hukum Islam.

Pembiayaan kepemilikan rumah yang merupakan salah satu pembiayaan favorit pada Bank Syariah Indonesia, saat ini menggunakan akad murabahah. Akad musyarakah mutanaqisa (MMQ) bisa menjadi alternative untuk diterapkan pada produk pembiayaan kepemilikan rumah atau kendaraan. Mengingat kebutuhan akan kepemilikan rumah dan kendaraan memang kebutuhan dasar semua masyrakat, sehingga pangsa pasarnya luas. Pada Bank Muamalat, KPR Muamalat iB dengan akad musyarakah mutanaqisa sangat diminati oleh masyarakat. Sejak diedarkanya surat dari BI pada tanggal 27 November 2012 dalam penerapan akad MMQ di Bank Syariah membuat perkembangan akad MMQ berkembang pesat dalam pembiayaan kepemilikan rumah yang berada di Indonesia, terakhir saat ini portfolio MMQ Bank Muamalat untuk KPR iB telah menembus 6,12\% pada tahun 2014 meningkat menjadi 14,52\% dibanding tahun 2013 yang mencapai 5,34 Trilyun (Harsanto,.2012). Portfolio MMQ di 2014 tersebut menempati share financing $36,63 \%$ dari pembiayaan musyarakah di Bank Muamalat, dan mencapai share financing $17,59 \%$ dari seluruh pembiayaan di Bank Muamalat.

Oleh karena itu, pengembangan produk bank syariah dengan akad musyarakah mutanaqisa perlu didorong. Pengetahuan dan pemahaman masyarakat mengenai akad yang terkategori masih asing ini perlu lebih diperhatikan kembali. Melalui berbagai acara 
seperti Focus Group Discution, seminar, atau sosialisasi bahkan dengan cara menulis atikel seperti ini bisa menjadi sarana penyampaian pengetahuan dan pemahaman kepada masyarakat. Sehingga penulis berpikir untuk mendeskripsikan mengenai akad musyarakah mutanaqisa ini. Apabila ini terus dilakukan, maka perkembangan produk kepemilikan rumah akan semakin meningkat. Ini didukung oleh data (OJK, 2014).

\section{Metode Penelitian}

Penelitian ini menggunakan metode penelitian kualitatif dengan menggunakan pendekatan studi kasus (case study). Lokasi penelitian ini dilakukan di Muamalat institute yang terletak di Tj. Duren Raya Raya No. No.7 ABC, RT.1/RW.6, Tj. Duren Utara, Grogol petamburan, Kota Jakarta Barat, Daerah Khusus Ibukota Jakarta 11470. Penetapan informan sebagai sumber data menggunakan teknik purposive sampling. Pengumpulan data menggunakan metode kualitatif dilakukan dengan wawancara mendalam, observasi dan dokumentasi untuk mengembangkan model kerja sama link and match untuk meningkatkan kesiapan kerja, Analisis data kualitatif: reduksi data, paparan data, dan penarikan kesimpulan data. Pendekatan studi kasus merupakan penelitian analisis deskriptif, yang mana penelitiannya berfokus pada suatu kasus tertentu yang diamati dan dianalisis secara cermat. Penelitian ini memusatkan diri terhadap kebutuhan tempat tingal bagi nasabah dengan menggunakan akad musyarakah mutanaqisa dan praktek musyarakah mutanaqisa di Indonesia.

\section{HASIL dAN PEMBAHASAN Musyarakah Mutanaqisa}

Musyarakah Mutanaqisah berasal dari dua kata Musyarakah dan Mutanaqisah. Musyarakah (syaraka-yusriku-syarkan-syarikan-syirkatan-syirkah), yang berarti bekerja sama, berkongsi, berserikat, atau bermitra (cooperation, partnership) dan Mutanaqisah (yatanaqishu-tanaqishan-mutanaqishun) berarti mengurangi secara bertahap (to diminish). Jadi Musyarakah Mutanaqisah merupakan suatu akad kemitraan/kerjasama untuk memiliki suatu barang secara bersama-sama dimana kepemilikan salah satu pihak akan berkurang dan pindah kepada rekanannya secara bertahap sampai menjadi utuh dimiliki satu pihak (edoc.musyarakah-mutanaqisah, 2015).

Hal ini sesuai dengan definisi yang diberikan oleh Fatwa Dewan Syari'ah Nasional No.73/DSN-MUI/XI/2008 pengertian Musyarakah mutanaqisah adalah musyarakah atau syirkah yang kepemilikan asset (barang) atau modal salah satu pihak (syarik) berkurang disebabkan pembelian secara bertahap oleh pihak lainnya. Keputusan Dewan Syarieah Nasional No: 01/DSN-MUI/XI/2013 Tentang Pedoman Implementasi Musyarakah Mutanaqisah Dalam Produk Pembiayaan, Definisi Produk: "Pembiayaan Musyarakah Mutanaqishah adalah produk pembiayaan berdasarkan prinsip musyarakah, yaitu syirkatul 'inan, yang porsi (hishshah) modal salah satu syarik (Bank Syariah/LKS) berkurang disebabkan pengalihan komersial secara bertahap (naqlul hishshah bil'iwadh mutanaqishah) kepada syarik yang lain (nasabah)."

Musyarakah Mutanaqisah (decreasing participation) adalah nasabah dan bank berkongsi dalam pengadaan suatu barang (biasanya rumah atau kendaraan) yang kepemilikannya bersama dimana semula kepemilikan Bank lebih besar dari Nasabah lama-kelamaan pemilikan Bank akan berkurang dan Nasabah akan bertambah atau disebut juga perkongsian yang mengecil. 
Gambar. 1 Skema Alur Transaksi Musyarakah Mutanaqisa (Aris, 2012)

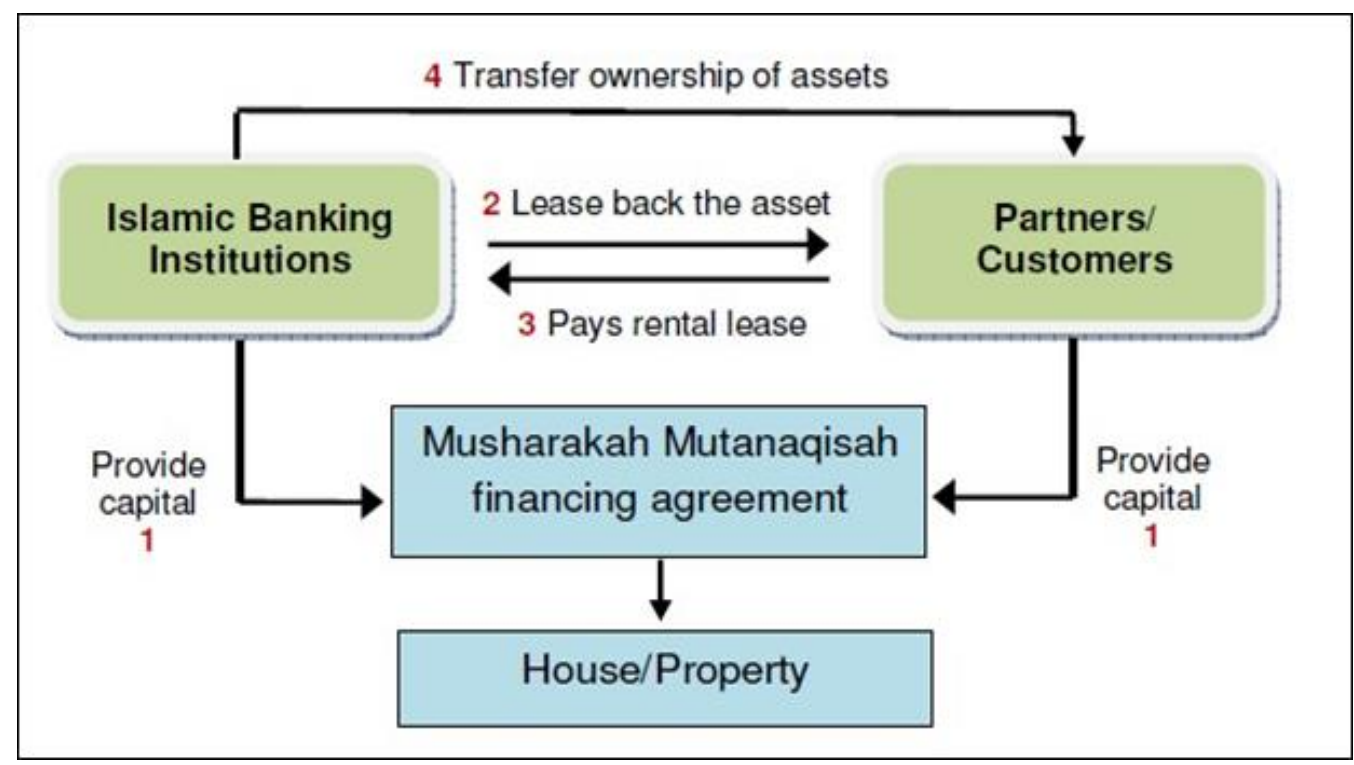

Analisis Perbandingan Manfaat Pembiayaan Musyarakah Mutanaqisah dan Murabahah Dalam Pembiayaan Perumahan

Perbandingan antara akad Musyarakah Muatanaqisah dengan akad Murabahah dalam dua fokus perbandingan, yaitu pertama mengenai karakteristik pembeda yang dimiliki masing-masing akad dan kedua mengenai kelebihan dan kekurangan dari masing-masing Akad. Perbedaan antara Akad Musyarakah Mutanaqisah dengan Akad Murabahah dapat dirincikan sebagai berikut:

a) Pengalihan hak tanda kepemilikan (levering)

Pada pembiayaan Musyarakah Mutanaqisah, hak tanda kepemilikan Bank baru beralih total kepada Nasabah setelah habis masa pembayaran sesuai kontrak karena porsi kepemilikan Bank berkurang sesuai dengan besar angsuran pembelian oleh Nasabah. Sedangkan pada pembiayaan Murabahah hak tanda kepemilikan (titles) beralih seketika dari Bank kepada Nasabah ditandai dengan pembuatan akta jual beli dengan nama Nasabah tercantum di dalamnya.

b) Karakteristik Perjanjian

Pada pembiayaan perumahan dengan menggunakan akad Musyarakah Mutanaqisah, terdiri dari tiga jenis akad: akad Musyarakah/ Syirkah, akad jual beli tangguh (Bai'), dan akad sewa (Ijarah). Pada pembiayaan perumahan dengan akad Murabahah hanya terdiri dari akad jual-beli (bai') saja dengan cara pembayaran angsuran.

c) Nilai Bagi Hasil

Akad Musyarakah Mutanaqisah dan Murabahah sama-sama termasuk kedalam jenis akad tijarah, yakni akad yang ditujukan untuk mencari keuntungan (profit). Jika dilihat berdasarkan tingkat kepastian dari bagi hasil yang diperolehnya, maka keduanya berlainan golongan. Akad Musyarakah 
Mutanaqisah termasuk kedalam golongan akad Natural Uncertainty Contract (NUC), yakni menawarkan return yang tidak pasti atau tidak tetap. Dasar perhitungan bagi hasil semata-mata ditentukan pada tarif sewa (Ijarah). Dalam arti, akad ini jika dipakai pada rumah yang uang sewanya lebih tinggi maka akan menguntungkan bank dan Nasabah dan terhadap rumah yang uang sewanya kecil maka keuntungan kedua pihak juga kecil dengan demikian bagi hasil menjadi tidak menentu besarnya, apalagi nilai sewa dapat dievaluasi.

Sementara akad Murabahah masuk dalam golongan akad Natural Certainty Contract (NCC), yakni memberikan return pasti dan tetap. Penentuan margin keuntungan Bank adalah nilai prosentase keuntungan terhadap harga agregat barang, yakni harga bank membeli barang secara tunai ditambah dengan biaya perolehan atas aset tersebut yang dikeluarkan oleh Bank. Dalam akad Musyarakah Mutanaqisah, margin bank tidak ditentukan oleh modal awal yang diberikan oleh bank maupun jangka waktu dari akad. Margin didasarkan pada nilai sewa rumah yang berlaku sehingga semakin lama masa pembiayaan akan semakin lama pula masa penyewaan dan akhirnya keuntungan bank juga semakin besar. Berbeda dengan akad Musyarakah Mutanaqisah, pada pembiayaan Murabahah Bank menentukan margin keuntungan berdasarkan harga beli dari developer ditambah dengan segala biaya yang dikeluarkan Bank dalam rangka memperoleh barang tersebut, seperti biaya pengiriman, pajak, dan sebagainya. Harga yang sudah dipengaruhi biaya-biaya ini dinamakan harga agregat yang kemudian menjadi penentu margin keuntungan Bank. Dalam teori, margin sebenarnya ditentukan dengan berpaku pada harga sewa pasar. Namun, Bank menginginkan sewa adalah rate margin yang dapat mengcover biaya-biaya dan risiko-risiko yang timbul akibat dari pembiayaan. Di samping itu, Bank perlu memperhatikan cost of fund dari bagi hasil dana pihak ketiga.

d) Angsuran

Angsuran pada pembiayaan rumah dengan akad Musyarakah Mutanaqisah dapat dilakukan evaluasi tiap tahun atau beberapa tahun sesuai dengan kesepakatan sementara pada akad Murabahah, angsuran bersifat tetap selama jangka waktu pembiayaan. Pada pembiayaan Musyarakah Mutanaqisah, total pembayaran sesuai dengan jumlah pembiayaan oleh bank, dengan kata lain total cicilan yang diterima oleh bank sama dengan jumlah pembiayaan dari bank.

Seandainya Nasabah ingin memiliki rumah tersebut sebelum jatuh tempo, Nasabah tidak akan dikenakan biaya tambahan, maksudnya Nasabah cukup melunasi sisa uang cicilan yang ada. Sedangkan pada pembiayaan Murabahah, total pembayaran cicilan didasarkan pada harga beli bank atas rumah dan margin keuntungan yang diinginkan Bank. Kedua komponen ini tidak dapat dipisahkan yang mana harus dibayar oleh Nasabah sampai masa kontrak selesai. Dengan kata lain, nasabah membayar angsuran perbulan berupa uang angsuran pokok untuk harga pembelian bank (harga beli Bank dibagi periode cicilan) ditambah angsuran keuntungan (margin rate bank dikali harga beli kemudian dibagi periode cicilan bank). Terhadap Nasabah yang ingin memiliki rumah tersebut sebelum jatuh tempo, maka nasabah akan dikenakan biaya tambahan berupa keuntungan bank berikut uang cicilan yang tersisa.

\section{Risiko yang timbul dalam Musyarakah Mutanaqishah}

Dalam pembiayaan akad musyarakah mutanaqishah (Abubakar, Handayani, 2017), posisi kepemilikan barang masih menjadi milik bersama (co-ownership) antara 
pihak bank syariah dan nasabah. Hal ini merupakan konsekuensi dari pembiayaan musyarakah mutanaqishah, dimana kedua belah pihak ikut menyertakan dananya untuk membeli barang. Oleh karena itu, terkait objek musyarakah mutanaqishah berupa Tanah dan Rumah, maka pengalihan kepemilikan merupakan perjanjian formal, yang harus dibuktikan dengan sertifikat.

Kedudukan Bank dan nasabah adalah mitra (partner), sehingga tidak tepat menggunakan mekanisme jaminan, khususnya Hak Tanggungan yang memberikan hak pada kreditor untuk mengeksekusi objek MMQ apabila Objek dijadikan objek jaminan. Diperlukan bantuan pranata hukum lain untuk mendukung penggunaan Hak Tanggungan, seperti kuasa atau perwakilan, mengingat hubungan Bank dan Nasabah bukanlah hubungan kreditor dan debitur dalam Hak Tanggungan (Abubakar \& Handayani, 2017).

Jika terjadinya pembiayaan berstatus macet, dan dilakukan penjualan atas asset musyarakah (rumah), maka hasil penjualan dilakukan penyelesaian sebagai berikut (Harsanto, 2015) :

Jika harga jual rumah lebih besar dari sisa outstanding pokok (sisa porsi yang dimilikiBank) maka hasil penjualan digunakan untuk menutup sisa outstanding terlebih dahulu, kemudian sisanya diberikan kepada nasabah. Hal ini bertentangan dengan prinsip bagi hasil dan bagi rugi dalam musyarakah. Dengan dasar prinsip musyarakah dimana para mitra memperoleh keuntungan berdasarkan nisbah yang disepakat pada saat akad dan menanggung kerugian sesuai proporsi modal (Fatwa DSN-MUI No.73/DSNMUI/XI/2008) , maka dengan kondisi penjualan asset ini, dilakukan sebagai berikut:

a) Hasil penjualan tetap didahulukan untuk menutupi outstanding pokok (porsi bank)

b) Setelah itu sisanya yang merupakan profit penjualan asset, tidak seluruhnya diberikan kepada nasabah, tetapi harus dibagi hasilakn sesuai dengan proporsi nisab bagi hasil yang disepakait pada saat akad.

Jika harga jual rumah lebih kecil dari sisa outstanding pokok (sisa porsi yang dimiliki Bank) maka hasil penjualan seluruhnya digunakan untuk menutup sisa outstanding, jika outstanding masih tersisa maka nasabah harus membayar kekurangan itu atau jika tidak mampu maka menjadi beban Bank. Hal ini juga bertentangan dengan prinsip bagi hasil dan bagi rugi dalam musyarakah. Dengan dasar prinsip musyarakah dimana para mitra memperoleh keuntungan berdasarkan nisbah yang disepakati pada saat akad dan menanggung kerugian sesuai proporsi modal, maka dengan kondisi penjualan asset ini, dilakukan sebagai berikut (DSN-MUI No.73/DSN-MUI/XI/2008) :

a) Hasil penjualan tetap didahulukan untuk menutupi outstanding pokok (porsi bank)

b) Sisa outstanding yang tidak tertutupi dari hasil penjual harus dibagirugikan terhadap kedua pihak yaitu Bank dan Nasabah sesuai dengan porsi kepemilikan sebelum dilakukan penjualan agunan (porsi terakhir).

Adapun mengenai masalah pajak maka seharusnya dipahami bahwa musyarakah mutanaqisah adalah skim pembiayaan yang berbentuk akad gabungan (hybrid contracts) untuk pembiyaan. Dengan demikian ijarah yang terdapat di dalamnya adalah ijarah yang bersifat pembiayaan (financial lease), bukan operating lease, karena itu dalam musyarakah mutanaqisah tidak boleh ada pajak (Umar, 2012). 


\section{Praktik Musyarakah Mutanaqisa di Indonesia}

Dalam aktivitas pembiayaan menggunakan Produk Musyarakah dan Musyarakah Mutanaqishah, perbankan syariah haruslah memastikan bahwa pelaksanaan pembiayaan sesuai dengan kepatuhan Syariah sebagaimana telah ditetapkan dalam berbagai ketentuan hukum Islam termasuk fatwa DSN. Namun seringkali timbul beberapa permasalahan dan isu terkait dengan kepatuhan syariah tersebut. Beberapa isu terkait penerapan produk Musyarakah dan Musyarakah Mutanaqishah di perbankan syariah di Indonesia yang terbagi dalam tiga isu permasalahan yaitu isu syariah, isu legal, dan isu operasional. Beberapa permasalahan tersebut antara lain . Pertama isu syariah terkait prinsip "dua akad dalam satu barang" ketika akad sewa dan beli disepakati dalam waktu yang sama. Kedua isu legal terkait perbedaan aturan fiqih dengan hukum positif Indonesia terkait pencatatan sertifikat kepemilikan. Ketiga, isu operasional terkait Isu independensi harga ketika pembiayaan musyarakah yang disertai pengalihan kepemilikan.

Musyarakah Mutanaqishah memiliki karakteristik khusus yang membedakannya dari model pembiayaan lainnya pada perbankan syariah. Karakter utama produk Musyarakah Mutanaqishah adalah sebagai berikut:

a) Hishshah, yaitu modal usaha para pihak harus dinyatakan dalam bentuk hishshah yang terbagi menjadi sejumlah unit hishshah.

b) Konstan, yaitu jumlah total nominal modal usaha yang dinyatakan dalam hishshah tersebut tidak boleh berkurang selama akad berlaku secara efektif.

c) Wa'd. yaitu bank syariah berjanji untuk mengalihkan secara komersial dan bertahap seluruh hishshahnya kepada nasabah.

d) Intiqal al milkiyyah, yaitu setiap penyetoran uang oleh nasabah kepada bank syariah, maka nilai yang jumlahnya sama dengan nilai unit hishshah, secara syariah dinyatakan sebagai pengalihan unit hishshah bank syariah secara komersial, sedangkan nilai yang jumlahnya lebih dari nilai unit hishshah tersebut, dinyatakan sebagai bagi hasil yang menjadi hak bank syariah.

Produk musyarakah mutanaqisah dapat diaplikasikan dalam bentuk pembiayaan yang bersifat produktif maupun konsumtif. Di Indonesia (Divisi Pengembangan Produk dan Edukasi Departemen Perbankan Syariah, 2016), jenis pembiayaan ini dapat diaplikasikan pada pembiayaan kendaraan (KKB), maupun pembiayaan properti atau rumah (KPR). Standar produk MMQ yang diuraikan dalam review ini masih terbatas pada pembiayaan MMQ untuk kepemilikan properti, khususnya rumah (KPR iB) dengan pertimbangan kebutuhan dan praktik di pasar industri perbankan syariah (Otoritas Jasa Keuangan, 2017)

Bank Syariah di Indonesia masih sedikit yang menawarkan produk dengan akad musyarakah mutanaqisa. Dari hasil peneusuran penulis melalui website dari 13 Bank Umum Syariah di Indonesia, ditemukan bahwa ada empat BUS yang menawarkan produk dengan akad musyarakah mutanaqisa, yakni Bank Muamalat, Maybank Syariah, Panin Bank Syariah dan Bank Mega Syariah. Keempat BUS tersebut menawarkan produk kepemilikan aset yakni kepemiikan rumah dan kendaraan. Dimana pada empat BUS tersebut, mereka juga menawarkan kepemilikan asset menggunakan akad murabahah. Sehingga nasabah bisa menenukan pilihan, akad mana yang akan mereka gunakan. BUS lainnya masih menggunakan hanya akad murabahah dalam produk kepemilikan rumah dan kendaraan. 
Fatwa yang mengatur mengenai akad musyarakah dan musyarakah mutanaqisa di Indonesia adalah Fatwa DSN Nomor. 08/DSN-MUI/ IV/2000 dan fatwa DSN Nomor: 73/DSN-MUI/ XI/2008. Dalam aturan tersebut dikatakan bahwa kepemilikan aset dapat dilakukan dengan cara menggunakan akad musyarakah mutanaqisa. Pada transaksi akad musyarakah mutanaqisa, pihak pertama (syarik) wajib berjanji untuk menjual seluruh hishshah (porsi) nya secara bertahap dan pihak kedua (syarik) wajib membelinya. Setelah selesai pelunasan penjualan, seluruh hishshah LKS beralih kepada syarik lainnya (nasabah). Aset musyarakah mutanaqisa dapat di-ijarah-kan kepada syarik ata pihak lain. Apabila aset musyarakah menjadi objekijarah, maka syarik (nasabah) dapat menyewa asset tersebut dengan nilai ujrah yang disepakati. Keuntungan yang diperoleh dari ujrah tersebut dibagi sesuai dengan nisbah yang telah disepkati dalam akad, sedangkan kerugian harus berdasarkan proporsi kepemilikan. Nisbah keuntungan dapat mengikuti perubahan proporsi kepemilikan sesuai kesepakatan para syarik.

\section{KESIMPULAN}

Berdasarkan hasil penelusuran dan pembahasan tentang analisis akad musyarakah mutanaqisah, dapat ditarik bahwa akad musyarakah mutanaqisah adalah syirkah yang kepemilikan asset (barang) atau modal salah satu pihak (syarik) berkurang disebabkan pembelian secara bertahap oleh pihak lainnya, memiliki rukun dan syarat yang hampir sama dengan musyarakah pada umumnya, namun memiliki kehendak memindahkan kepemilikan porsi asset. Syirkah ini yang dijadikan obyek ialah porsi kepemilikan asset. Praktik musyarkah mutanaqisah dalam perjalanannya nampaknya sudah menggunakan pedoman DSN-MUI, bahkan sebagian lebih diatur secara rinci dan benar.

Akad ini menjadi inovasi baru bagi Bank Syariah di Indonesia dalam memenuhi kebutuhan masyarakat. Akad ini lebih baik jika dibandingkan dengan conventiona lease yang secara sepintas seolah tampak sama dengan akad musyarakah mutanaqisa. Akad musyarakah mutanaqisa mengguakan PSAK 106 tentang musyrakah dalam perlakuan akuntansinya. Fatwa Fatwa DSN Nomor. 08/DSN-MUI/ IV/2000 tentang musyarakah dan Fatwa DSN Nomor: 73/DSN- MUI/XI/2008 tentang akad musyarakah mutanaqisa memperbolehkan akad ini berlangsung. Di Indonesia, empat dari 13 Bank Umum Syariah menawarkan produk dengan akad musyarakah mutanaqisa, yakni pada pembiayaan kepemilikan rumah dan kendaraan. Selain di Indonesia, juga telah banyak bank syariah yang menerapkan akad ini

\section{REFERENSI}

Abubakar, Lastuti, Tri Handayani. 2017. Telaah Yuridis terhadap Pembiayaan Perumahan Melalui Akad Musyarakah Mutanaqisah (MMQ) Sebagai Alternatif Pembiyaan Perumahan dalam Upaya Pengemabangan Produk Perbankan Syariah. Jurnal Hukum Ekonomi Islam, Vol. 1, No. 1. hlm. 17

Aris, Nooraslinda Abdul, dkk. 2012. Islamic House Financing: Comparison between Bai Bithamin Ajil (BBA) and Musyarakah Mutanaqisah (MM). African Journal Of Business Management, Vol. 6, No. 1, pp. 269

Divisi Pengembangan Produk dan Edukasi Departemen Perbankan Syariah. 2016. Standar Produk Perbankan Syariah Musyarakah Mutanaqishah. Otoritas Jasa Keuangan: Jakarta 
Faizin, Mu'adil. 2017. Keabsahan Klausula Eksonerasi Perjanjian Baku Dalam Perspektif Hukum Islam. Istinbath, Vol 14 No 1

Heykal, Mohamad \& Nurul Huda. 2010. Lembaga Keuangan Islam Tinjauan Teoritis Dan Praktis, Jakarta: Kencana

Fatwa DSN-MUI Nomor: 08/DSN-MUI/ XI/2000

Fatwa DSN-MUI Nomor: 73/DSN-MUI/ XI/2008

Undang-Undang Nomor 21 Tahun 2008 tentang Perbankan Syariah

Umar, Ridwan. Implementasi Musyarakah Mutanaqisah sebagai Alternatif Pembiayaan Murabahah di Perbankan Syariah Indonesia. Medan: Fakultas Syariah Institut Studi Islam Darussalam (ISID) Gontor 